\title{
OPINION
}

\section{The European Refugee Crisis from a Vantage Point of View}

\author{
Marjoleine Zieck
}

\section{Introduction}

Europe is confronted with what is invariably referred to as a 'crisis': an ongoing influx of refugees mainly but not exclusively from Syria. Although the root cause of flight - the brutal Syrian civil war - rages already for five years, Europe appears to have been caught by surprise as a result of which individual states resort to taking unilateral measures with a view to stemming the flow. A rather popular measure appears to be the hasty erection of fences. The fall of the Berlin wall, long a symbol of a profound division within Europe, has been forgotten and new grim divisions are created: this time not to prevent people from leaving but to prevent them from entering and accessing protection. Barbed wire fences and walls have been erected within a very short time between Hungary and Serbia, Hungary and Croatia, Greece and Macedonia, Croatia and Slovenia, Bulgaria and Turkey, and Greece and Turkey. ${ }^{1}$ Other unilateral measures include the recently adopted Danish law that allows the seizure of assets (money and valuables exceeding 1300 euro) from incoming refugees, ${ }^{2}$ and the quotum set by Austria regarding the maximum number of refugees who may apply for asylum: 127,500 refugees within four years (i.e., 37,000 per year). ${ }^{3}$

The EU too appears to be in disarray: attempts to relieve Greece and Italy by relocating 160,000 refugees within Europe proceeded so slowly that the President of the European Commission predicted that, at this pace, the relocation could only be realized by the year $2101 ;^{4}$ the EU 'hotspots' in Italy and Greece were estab-

1 The building of fences is ongoing, cf. The Economist, 'More Neighbours Make More Fences', Daily Chart, January 7, 2016, <www.economist.com/blogs/graphicdetail/2016/01/daily-chart-5> (accessed 28 March 2016).

2 D. Crouch and P. Kingsley, 'Danish parliament approves plan to seize assets from refugees', The Guardian, January 26, 2016, <www.theguardian.com/world/2016/jan/26/danish-parliamentapproves-plan-to-seize-assets-from-refugees $>$ (accessed 28 March 2016).

3 Leonhard Foeger, 'Austria to cap refugee flow at 3,200 a day, with Slovenia's help', Reuters, February 17, 2016, <http://uk.reuters.com/article/uk-europe-migrants-austria-idUKKCNOVQ1OD> (accessed 28 March 2016).

4 President Juncker, 'European Commission - Daily News', November 13, 2015, <http://europa. eu/rapid/press-release_MEX-15-6080_en.htm> (accessed 26 March 2016). 
lished so slowly that their purpose was defeated before they were all operational; ${ }^{5}$ and the latest deal with Turkey - known as the 'EU-Turkey deal' ${ }^{6}$ - of 18 March is fraught with legal problems such as the blanket return of all irregular migrants who arrive in Greece to Turkey, as if the latter is a 'safe third country', and the ethically problematical, meanwhile qualified as Kafkaesque, resettlement of one Syrian refugee in the EU for every Syrian readmitted in Turkey from Greece. ${ }^{7}$

Meanwhile, politicians and media engage in qualifications that tend to dehumanize those who are forced to flee: references are made to the refugees in terms of 'invasion', 'tsunami', and 'swarms'. ${ }^{10}$ On occasion, these predicates are coupled with invoking populist fears of terrorism, crime, anti-Semitism, homophobia, and a Muslim majority population within Europe. ${ }^{11}$ In short, an image is created that instils fear: the other as a threat.

5 On the hotspots, see European Commission Communication to the European Parliament, the European Council, and the Council on managing the refugee crisis: immediate operational, budgetary, and legal measures under the European Agenda on Migration COM(2015) 490 final/2, Annex II. In the EU-Turkey deal (see infra), the hotspots are charged with facilitating returns to Turkey and that may mean the end of them: Al-Jazeera, 'UNHCR, MSF withdraw from Greece's refugee "hotspots"', Al-Jazeera, March 22, 2016, <www.aljazeera.com/news/2016/03/aid-groupswithdraw-greece-refugee-hotspots-160322202842234.html> (accessed 28 March 2016).

6 See the European Council, Council of the European Union, 'EU-Turkey statement', Press Release 144/16, March 18, 2016, <www.consilium.europa.eu/en/press/press-releases/2016/03/18-euturkey-statement/> (accessed 28 March 2016).

7 Cf. 'UNHCR slams EU-Turkey migrant deal, places refugees at risk', ANSAmed, March 18, 2016, <www.ansamed.info/ansamed/en/news/sections/politics/2016/03/18/unhcr-slams-eu-turkeymigrant-deal-places-refugees-at-risk_7b7eb369-eb05-4b97-9513-442fd47a403c.html> (accessed 26 March 2016); 'EU-Turkey deal a historic blow to rights', Amnesty International, March 18, 2016, 〈www.amnesty.ie/news/eu-turkey-deal-historic-blow-rights> (accessed March 26, 2016); 'EU leaders agree on EU-Turkey Deal despite serious concerns over its consequences for human rights of refugees and migrants', ECRE, March 25, 2016, <www.ecre.org/component/content/ article/70-weekly-bulletin-articles/1434-eu-leaders-agree-on-eu-turkey-deal-despite-seriousconcerns-over-its-consequences-for-human-rights-of-refugees-and-migrants-.html> (accessed 26 March 2016).

8 Just one example, but many others could be given: A.C. Chrysafis, 'Refugee Invasion of Europe', Greek Reporter, October 4, 2015, <http://greece.greekreporter.com/2015/10/04/refugee-invasion -of-europe/> (accessed 26 March 2016).

9 'Czech President Predicts 2016 “Tsunami” of Young Male Refugees', Sputnik News, January 26, 2016, 〈http://sputniknews.com/europe/20160126/1033730289/zeman-refugee-tsunami.html> (accessed 26 March 2016).

10 Prime Minister David Cameron, 'PM blames Calais crisis on “swarm” of migrants,' ITV News, 30 July 2015, 7:00 am, available at <www.itv.com/news/update/2015-07-30/pm-a-swarm-ofmigrants-want-to-come-to-britain/> (accessed March 28, 2016). For more in general on the manner in which refugees are qualified, see Samuel Parker, "Unwanted Invaders": The representation of refugees and asylum seekers in the UK and Australian print media' Myth and Nation Spring 2015, 23 <www.gla.ac.uk/media/media_404384_en.pdf> (accessed 28 March 2016).

11 Prime Minister Viktor Orbán of Hungary is very vocal and wholly unrestricted on all listed issues, see e.g., Kai Diekmann, 'Hungary’s Prime Minister says accepting Syrian refugees "also means importing terrorism, criminalism anti-Semitism, and homophobia”, UK Business Insider, February 25, 2016, <http://uk.businessinsider.com/viktor-orban-interview-refugee-migrant-hungary -2016-2?r=US\&IR=T > (accessed 28 March 2016). 
Among the politicians, there are a few, Chancellor Angela Merkel in particular, who call for and act upon the need to provide protection to the refugees, but otherwise, too few seem to remember why the contemporary international regime consisting of the Office of the United Nations High Commissioner for Refugees (UNHCR), its Statute, the 1951 Convention Relating to the Status of Refugees (hereafter: 1951 Convention), ${ }^{12}$ and the 1967 Protocol Relating to the Status of Refugees (hereafter: 1967 Protocol) - was created in the wake of the Second World War. It therefore seems timely to consider the current sorry state of affairs from a vantage point of view: first the perspective of factual evidence and secondly, the perspective of history, and thirdly, that of morality.

\section{Factual evidence}

There are two reasons to view the current situation in Europe from the perspective of actual facts and figures. First, it serves as a reality check to counter the often - facile statements made regarding the size of the influx, and secondly, because the figures demonstrate that the call for sheltering refugees in the region of origin - a solution waved around by politicians like a magic wand - is manipulative.

Focusing on Syrian refugees, the total number of Syrian refugees amounts to 4,8 million persons as of 16 March $2016 .^{13}$ They are predominantly hosted by neighbouring states: 1,1 million refugees in Lebanon; 635,324 in Jordan; 2,5 million refugees in Turkey; 245,022 in Iraq; and 117,685 in Egypt. ${ }^{14}$ These figures mean that about $90 \%$ of the Syrian refugees stay in their region of origin. ${ }^{15}$

It is worthwhile to note that unlike European states, Lebanon and Jordan are not party to the 1951 Convention and that Turkey has confined its obligations under the 1951 Convention to European refugees. ${ }^{16}$ In comparison, it is estimated that between April 2011 and September 2015, about 512,000 Syrian refugees applied for asylum in Europe. ${ }^{17}$ Seen in light of the number of Europeans, the number of Syrians claiming asylum amounts to just $0.1 \%$ of the European population. If the total number of refugees arriving in Europe in 2015 is considered, the percentage is $0.2 \%$.

Text of the 1951 Convention is available at <www.unhcr.org/3b66c2aa10.html>.

13 UNHCR, 'Syria Regional Refugee Response', Inter-Agency Information Sharing Portal, March 16, 2016, <http://data.unhcr.org/syrianrefugees/regional.php> (accessed 28 March 2016).

14 'Syria's refugee crisis in numbers', Amnesty International, February 3, 2016, <www.amnesty.org/ en/latest/news/2016/02/syrias-refugee-crisis-in-numbers/> (accessed 26 March 2016).

15 Ibid.

16 It could opt to do so by virtue of Art. 1 B (2), 1951 Convention.

17 That is, those who survived the attempt to reach Europe. For estimated figures of those who did not, see the figures of the Missing Migrants Project at <http://missingmigrants.iom.int/> (accessed 28 March 2016). See also 'The rising death toll in the Mediterranean Sea', Amnesty International UK, April 19, 2015, <www.amnesty.org.uk/worlds-deadliest-sea-crossingmediterranean> (accessed 28 March 2016). 


\section{Some historical observations}

'Today's system of international refugee protection was born out of the Holocaust'. ${ }^{18}$

This is a very short and unambiguous summary of the origin, and simultaneously the rationale, of the current international legal regime pertaining to refugees made by the then United Nations High Commissioner for Refugees, Madame Ogata.

The 1951 Convention, the heart of today's system, was the first human rights treaty drafted after the Second World War, and it defines protection in terms of human rights. Since its origin is cast in terms of the genocide that took place during World War II, it is worth recalling that attempts to save the persecuted Jews came to naught preceding and during that War. Preceding World War Two, many attempted to flee Germany, but they were not welcome abroad. The Evian conference in 1938, which sought to find a solution for the German-Jewish refugees, failed, and the 908 Jewish refugees on board the ocean liner St. Louis that left Hamburg in 1939 were prevented from disembarking in Havana and Miami and were returned to Europe.

Those events resemble what we are now witnessing: many European states closing their borders to refugees, thousands of refugees trying - too often in vain - to reach Europe by boat, and arduous negotiations in the EU to reach (too late, too modest, and legally and morally questionable) solutions. All this despite the fact that Europe has, unlike the past, a refugee Convention - not to mention the common European asylum system - that was meant to address problems such as these. There are other uneasy parallels between the current situation and that of the pre-1939 refugees. First, the root cause of flight:

"The similarity in both instances - pre 1939 refugees and post 1945 refugees - there was no direct threat of annihilation (also not in the time of the St. Louis). The Syrians run from IS - at least as great an imminent threat as the pre 1939 and post 1945 refugees. Assad and IS have very little scruples, they will happily destroy everyone they consider to be problematic" ${ }^{19}$

Secondly, the way the refugees are perceived:

'The international community is looking at the hundreds of thousands, and they are unfortunately stuck with a not inconsiderable fear because of their

18 'Preventing Future Genocide and Protecting Refugees', Address by Mrs Sadako Ogata, United Nations High Commissioner for Refugees, at the Holocaust Memorial Museum, Washington, D.C., April 30, 1997.

19 Interview with Professor Menachem Rosensaft on October 12, 2015, New York. Professor Rosensaft teaches the Law of Genocide in the law schools of Cornell and Columbia in New York and is the legal counsel of the World Jewish Congress. 
ethnic identity: Muslims and Arabs. The hype - regardless of the fact that it is an extreme and inaccurate over-generalization - that all Muslims are radical Jihadists is seriously affecting the conversation. The question becomes, if we take in $\mathrm{x}, \mathrm{y}$ or $\mathrm{z}$ numbers of refugees, are we importing dangerous individuals? In 1939, German Jews were arrested as enemy aliens' ${ }^{20}$

\section{Morality}

The 1951 Convention recognizes in its Preamble that the grant of asylum may place unduly heavy burdens on certain countries and that a satisfactory solution to the problem, which the United Nations has recognized as being international in scope and nature, cannot therefore be achieved without international co-operation. This preambular phrase is not binding nor does it have a binding counterpart in the body of the Convention. Geographical proximity, buttressed by the prohibition of refoulement, ${ }^{21}$ therefore serves as the sole distributive mechanism. As a result, neighbouring states are disproportionately burdened, and there is no obligation for other states to relieve them.

The fact of disproportionate burdens is not new: Pakistan was for some 30 years the state hosting most of the world's refugees - it hosted many millions of Afghan refugees, and it still does (whilst not being a party to the 1951 Convention). Furthermore, $86 \%$ of the world's refugees are hosted by developing countries and $25 \%$ of the global total by the least developed states, ${ }^{22}$ but these facts never induced addressing this systemic omission in the 1951 Convention.

In Europe, the lack of a distributive mechanism is compounded by the Dublin regulation that causes the states that form the outer border of the EU, particularly Greece and Italy, to be disproportionately burdened within the EU without other EU member states unburdening them. ${ }^{23}$ Recent attempts to relieve those states by means of relocating 160,000 refugees to other European states have come to

20 Ibid. See also M. Rosensaft, 'We Cannot Turn Our Back on the Refugees from ISIS Barbarity', Huffington Post, November 23, 2015, <www.huffingtonpost.com/menachem-rosensaft/we-cannot -turn-our-back-o_b_8624260.html> (accessed 26 March 2016).

21 See Art. 33(1), 1951 Convention. This particular prohibition is also part of customary international law.

22 UNHCR, 'World at War: Global Trends Forced Displacement in 2014', 2015, <http://unhcr.org/ 556725e69.html>, 2.

23 'Dublin', more in particular the Dublin III regulation (in full: Regulation (EU) No. 604/2013 establishing the criteria and mechanisms for determining the Member State responsible for examining an application for international protection lodged in one of the Member States by a third-country national or a stateless person (recast)), was created in the EU to prevent forumshopping by refugees, and to identify the state responsible for processing their asylum applications, which generally speaking is the state where the refugee arrives first. In case a refugee moves on and requests asylum in another European state, that state may send the refugee back to the first state. 
naught: only 660 have been relocated so far, ${ }^{24}$ a number that does not bode well for the recently concluded 'Turkey deal' that includes sharing responsibility for Syrian refugees who are, under the terms of the deal, entitled to resettlement in Europe.

Naturally, the interests of states are different from those of individuals, but what appears to be lacking in the current debates is recognition of the arbitrariness of the fate of individuals: no one can choose his or her place of birth; it is an accident of the human condition. International human rights law is an attempt to even out the unequal condition and chances of individual persons. International refugee law is a mechanism that ensures that the subject - the country of origin - who is responsible to accomplish this (in terms of civil, political, economic, social, and cultural rights) is substituted by another state - the country of refuge - for the duration of need for protection. In other words, the instruments that were adopted in the wake of the Second World War are permeated by the decision to protect individuals by means of human rights and in addition to secure this protection from another, substitute or back-up state for those - refugees - who are forced to flee the (anticipated) sustained or systematic violation of those human rights in their country of origin. ${ }^{25}$

\section{Conclusions drawn from a vantage point of view}

The decision to ensure substitute protection for refugees in the sense indicated appears to have been forgotten. ${ }^{26}$ Yet if the number of refugees is taken into consideration, particularly set against the number of Europeans, there is no reason to do so. Of course, there are many practical considerations and concerns that need to be addressed, not in the least that of ensuring an end to the extremely perilous way to reach Europe by crossing the Mediterranean Sea, and legitimate fears about safety. ${ }^{27}$ But in final analysis, Europe should observe its international obligations, ${ }^{28}$ live up to its own standards ${ }^{29}$ - which were not solely meant to be applied in good times but are arguably intended to ensure protection in bad times

24 J. Henley, 'EU Refugee relocation scheme is inadequate and will continue to fail', The Guardian, March 4, 2016, <www.theguardian.com/world/2016/mar/04/eu-refugee-relocation-schemeinadequate-will-continue-to-fail> (accessed 28 March 2016); Cf. the observation of President Juncker referred to in para 1 supra.

25 Cf. Canada (Attorney General) v. Ward, [1993] 2 S.S.R. 689, Canada: Supreme Court, June 30, 1993.

26 It elicited the following disturbing observation on the part of Professor Rosensaft: 'We are now witnessing in Europe, a xenophobic and highly disturbing nostalgia for fascism of a kind I haven't seen in my lifetime', interview October 12, 2015.

27 It should be added in this respect that refugee status determination includes verifying whether a person should be excluded on account of serious reasons for considering that he has committed war crimes, crimes against humanity, serious non-political crimes, see Art. 1 F, 1951 Convention.

28 In particular those incurred by virtue of the 1951 Convention and 1967 Protocol (all European states are party to those instruments).

29 Cf. in particular the Preamble to the Statute of the Council of Europe, and the Preamble to the 1950 European Convention on Human Rights and Fundamental Freedoms. 
- and, in addition, share the responsibility of protecting those who are entitled to that protection in an equitable manner. Hannah Arendt observed in 1943 that:

'The comity of European peoples went to pieces when, and because, it allowed its weakest member to be excluded and persecuted'. ${ }^{30}$

There is a risk that this comity may shatter once again, this time not on account of exclusion of a member but on account of a turning away from the rule of law that was created in the wake of the Second World War to prevent exactly that from recurring.

30 Hannah Arendt, 'We Refugees', in Altogether Elsewhere: Writers on Exile, ed. Marc Robinson, 1st ed. (Boston: Faber \& Faber, 1994), 119. This essay was first published in 1943. 